\title{
NATUREZA E SOCIEDADE: NOVOS URBANISMOS E UM VELHO DILEMA
}

\author{
José Otávio Lotufo \\ Arquiteto e urbanista pela Faculdade de Belas Artes da São Paulo (1996), mestre na área de \\ Projeto Arquitetônico pela FAU-USP (2011). - E-mail: zkltf@uol.com.br
}

\begin{abstract}
Resumo
Uma vez que o planejamento sustentável passou a ser unanimidade e uma nova agenda para enfrentar novos desafios uma necessidade, as questões agora levantadas dividem opiniões no "como" fazer. Recentes discussões têm apresentado duas importantes tendências, uma se volta ao passado, à cidade tradicional, e a outra olha o futuro, clamando por uma vanguarda ecológica. Se estas abordagens são contraditórias ou complementares é a questão que o presente artigo pretende levantar. Desde uma breve síntese histórica até as recentes discussões entre o Novo Urbanismo e o Landscape Urbanism, esta questão se revela não como nova, mas como perene e inerente ao próprio espírito humano.
\end{abstract}

Palavras chave: Planejamento ambiental, desenvolvimento sustentável, ecologia urbana, ecossistemas, arquitetura, urbanismo. 


\title{
NATURE AND SOCIETY: NEW URBANISMS AND AN OLD DILEMMA
}

\begin{abstract}
Once the sustainable planning became unanimity, and a new agenda to tackle new challenges a need, the questions now raised divided opinions on the "how" to do it. Recent discussions have shown two important trends, one turns to the past, the traditional city, and the other looks at the future, calling for an ecological avant-garde. If these approaches are complementary or contradictory is the question that this paper aims to raise. Since a brief historical overview to recent discussions between New Urbanism and Landscape Urbanism, this question is revealed not as new, but as perennial and inherent to the human spirit.
\end{abstract}

Keywords: environmental planning, sustainable development, urban ecology, ecosystems, architecture, urbanism.

\section{INTRODUÇÃO}

Em 2010, na Universidade de Harvard, um congresso intitulado Ecological Urbanism desencadeou uma discussão que retoma um dilema recorrente na história do desenho urbano: o modo como natureza e espaço construído se compõe na formação das cidades. Este evento marcou um reajuste importante no programa de ensino de planejamento e desenho urbano da Harvard GSD (Graduate School of Design). A novidade é uma maior relevância da paisagem como fator determinante no planejamento urbano e territorial e o aprofundamento na abordagem ecológica do projeto.

Adres Duany, um dos principais articuladores do movimento Novo Urbanismo afirmara num artigo da Metropolis Magazine ${ }^{1}$ que estaria ocorrendo um golpe na Harvard GSD para derrubar seu "venerável programa de desenho urbano" e substituí-lo pelo Landscape Urbanism, ou o urbanismo da paisagem. Alex Krieger, então diretor daquele departamento e conhecido crítico do Novo Urbanismo tratou de desmenti-lo em outro artigo ${ }^{2}$. O

1 www.metropolismag.com/pov/20101103/duany-vs-harvard-gds

2 www.metropolismag.com/pov/20101108/krieger -to-duany 
projeto da paisagem estava sim reafirmando sua importância no planejamento urbano, antes relegado a segundo plano, mas de forma alguma isto significava a substituição de uma séria disciplina acadêmica inaugurada por Frederick Law Olmsted, Jr. em Harvard nos anos 20 , e muito menos um golpe.

Uma vez que o horizonte do desenvolvimento sustentável passou a ser unanimidade, as questões agora levantadas dividem o caminho entre correntes que concordam sobre a necessidade de uma nova agenda, mas divergem no "como" fazer. Esta conversa tomou rumo com dois importantes movimentos atuais do projeto urbano. De um lado o Novo Urbanismo, um movimento que vem tomando corpo desde a década de 70 e tem se focado na revaloração de características tradicionais de planejamento: vizinhança, adensamento, valorização do pedestre, uso misto do solo e preservação ambiental. Do outro lado o Landscape Urbanism, um movimento mais recente que clama por uma abordagem mais ecológica do desenho, que respeite e tome partido das condições e infraestruturas naturais preexistentes.

Vistos de perto à luz das diversas críticas, tanto o NU como o LU trazem preceitos importantes, mas apresentam também suas fragilidades. Antes de expor de forma mais detalhada a confrontação destes dois pontos de vista, seria útil situá-los como continuidade de uma trajetória histórica, destacando o modo como foi pensada a relação civilização/natureza e o lugar do homem como artífice e integrador destas dimensões, por vezes de forma polarizada, mas também e mais raramente, de forma mais integrativa e equilibrada.

\section{VELHO DILEMA}

O dilema entre natureza e civilização é tão antigo quanto nossa história. Na mitologia sumeriana, escrita na idade do bronze, o herói Gilgamesh, parte homem parte deus, luta contra "seres naturais". Em suas vitórias, sofre em seu íntimo a contradição entre o cuidado e a hostilidade, entre honra e arrependimento, o que o levara a contínuas reavaliações sobre seus atos. Enquanto a cidade-estado de Uruk se mantinha pelo domínio do homem sobre a natureza, a ira dos deuses, por vezes, se manifestava em desastres naturais que afetavam a cidade e sua população ${ }^{3}$.

3 LIMA, Cathartina P.C. dos Santos, Natureza e Cultura: O conflito de Gilgamesh, em

Paisagem e ambiente: Ensaios, n.o 18, São Paulo 2004 
Em A Cidade na História, Lewis Munford cita as cidades gregas de Cós, Cnido e Epdauro (sec.V e IV a.C). Símbolos da preocupação grega com a integridade e o equilíbrio teriam deixado grandes lições para o urbanismo. No tratado hipocrático $A r$, água e lugares, são apresentadas diretrizes de saneamento que partem da localização ideal de cidades e dos edifícios, levando em conta insolação e ventilação natural, evitando áreas alagáveis e provendo abundância de água limpa, teoria retomada por Vitrúvio no século I d.C. nas cidades de colonização romana.

Na Idade Média, a cisão entre natureza e civilização foi reforçada pela moral religiosa, que somada à necessidade de proteção às invasões resultou em cidades muradas. Metáfora de uma condição cultural, a muralha é forte alusão à dualidade entre matéria e espírito. Em outra instância simboliza a cisão entre natureza e civilização. A natureza, vista como lugar da corrupção, do pecado, da hostilidade, da selvageria, se opunha ao conforto, à proteção, à moral religiosa e à virtude, "protegidos" do lado de dentro de suas muralhas.

Com o fim da Idade Média e início da Era Moderna, Andrea Palladio retoma as ideias clássicas sob uma nova realidade política e social. Em sua obra os elementos naturais, como topografia e vegetação, participam na composição do espaço, rompendo com a ideia da natureza enquanto lugar hostil. A mesma relação se deu na cidade entre o edifício e praça pública. Ao inseri-lo num contexto maior supera a ideia do edifício como entidade isolada.

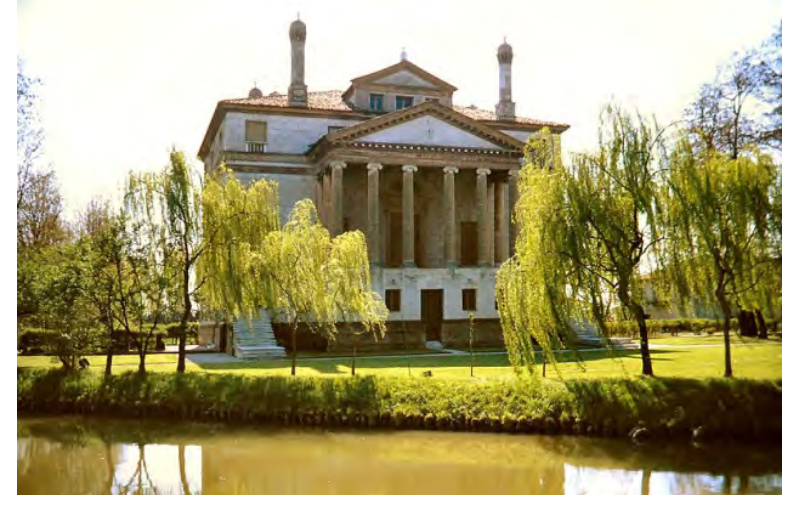

Figura 1: Villa Foscari, Palladio www.panoramio. com/photos/

Em 1617 Inigo Jones leva a influência de Palladio à Inglaterra com o projeto da Queen's House em Greenwich. A arquitetura palladiana vinha de encontro aos princípios do jardim inglês onde os elementos se compõem de forma orgânica e irregular. A reforma no século XVIII da cidade de Bath ${ }^{4}$, permeada de jardins naturalistas, tornou-se referência para o amadurecimento das ideias que culminaram mais tarde com o modelo das cidades-jardins. (LOTUFO)

4 OTTONI, Dácio Araújo B. Cidade Jardim: Formação e Percurso de uma Idéia. Introdução à edição brasileira de Cidades-Jardins de Amanhã 


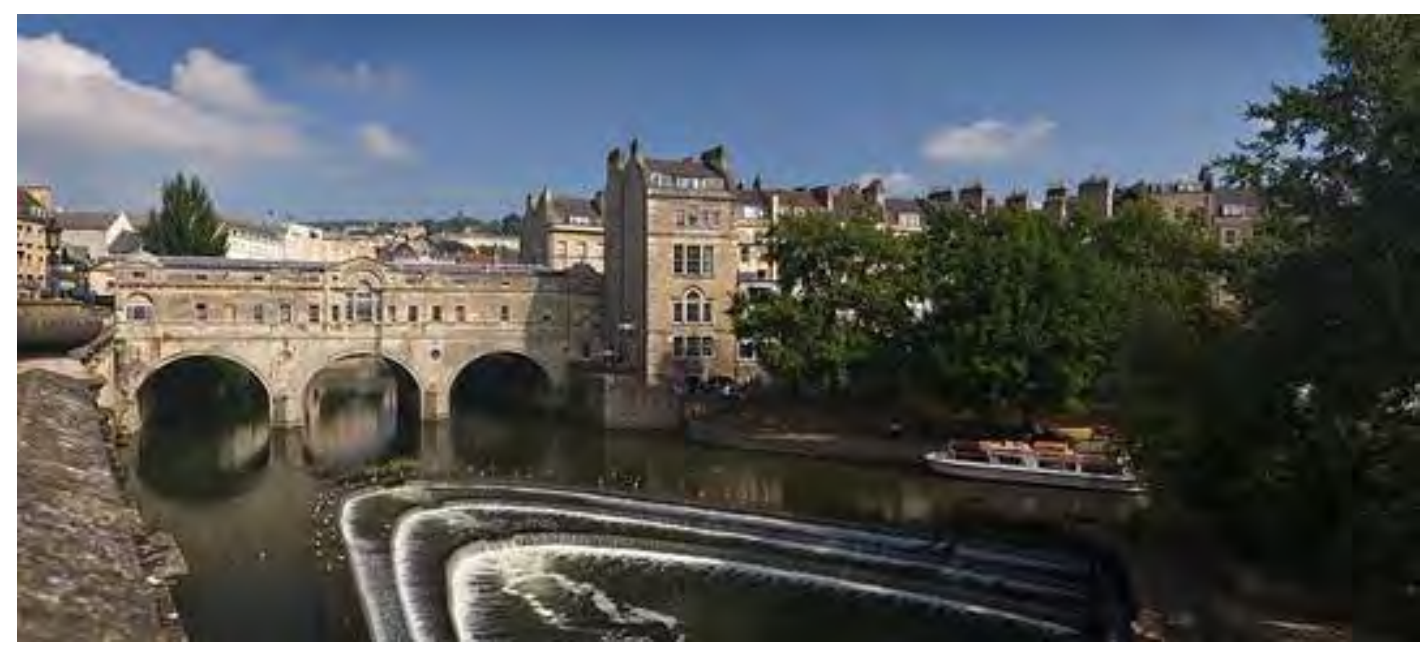

Figura 2: Cidade de Bath, Inglaterra. Fonte: Bath; http://pt.wikipedia.org/wiki/Ficheiro:Pulteney_bridge_in_Bath_view_from_south_before_noon.jpg

\section{INDUSTRIALIZAÇÃO E UTOPIA}

A revolução industrial impunha profundas mudanças na vida das populações urbanas. A precariedade das habitações operárias estimulava o florescimento do socialismo utópico pelo qual a natureza seria a solução para os "males da civilização". No século XIX, Robert Owen, expulso da Inglaterra por suas ideias subversivas, propôs nos EUA a colônia de New Harmony, uma comunidade industrial campestre. No mesmo espírito, na França, Charles Fourrier propunha os falanstérios, partindo do princípio de que o ser humano possuía uma bondade implícita sufocada pelo modo de vida da época. Apesar do insucesso destas comunidades, seus ideais tiveram grande influência sobre o pensamento urbanístico que se seguiu.

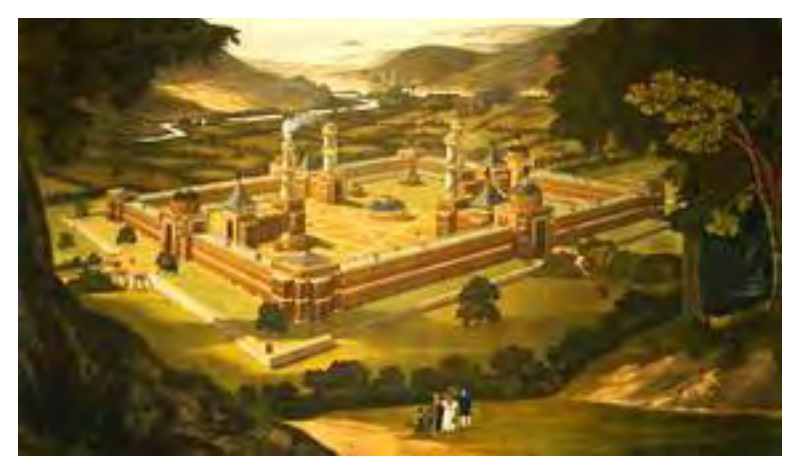

Figura 3: New Harmony, Indiana, EUA.. Ilustração de 1838. Fonte: http://commons.wikimedia.org/ 
Na segunda metade do século XIX frente à racionalização da produção industrial que tornava o trabalho mecânico e alienado, surgia na Inglaterra o Arts \& Crafts, movimento liderado por Willian Morris que enfatizava a sensibilidade em oposição à razão. O objetivo foi restituir ao trabalhador sua condição de artesão, reintroduzindo na manufatura o traço de seu trabalho. Frente à massificação da produção da moradia e a crescente deterioração de suas condições nas cidades industriais o Arts \& Crafts teve uma importância marcante para a arquitetura e desenho urbano.

Sempre houvera na Inglaterra uma tradição de amor à vida no campo. A ascensão de uma nova burguesia industrial urbana havia originado bairros residenciais nobres com extensa vegetação, refletindo a necessidade de manter vínculos com a natureza. 0 desenho urbano, tecido de maneira orgânica, integrava-se às formas naturais através de caminhos sinuosos e extensos gramados para o encontro e o convívio. Londres se tornava uma das principais referências sobre o futuro das cidades. No entanto, no final do século XIX esta realidade, reservada a poucos, conflitava fortemente com os bairros operários ao sul do Rio Tâmisa. $\mathrm{O}$ descompasso entre desenvolvimento econômico e social se evidenciava na precariedade da vida da população mais pobre. A habitação apresentava problemas graves com superpopulação, péssimas condições de higiene, ausência de saneamento e proliferação de diversos tipos de doenças.

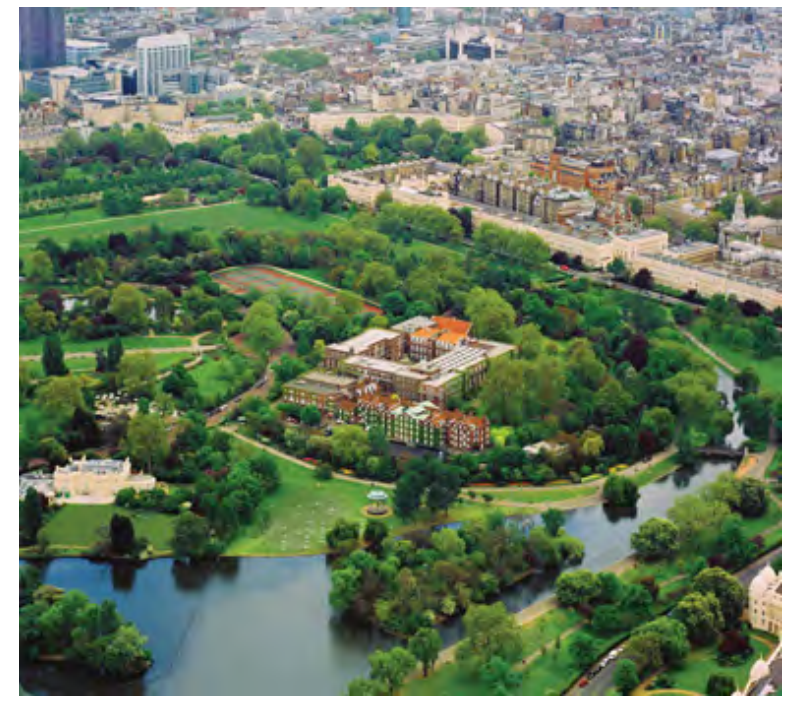

Figura 4: Regent's Park. Fonte: http://www.adventureballons.co.uk/productis-Iondon.html

Figura 5: Bairro operário em Londres, por Gustave Doré

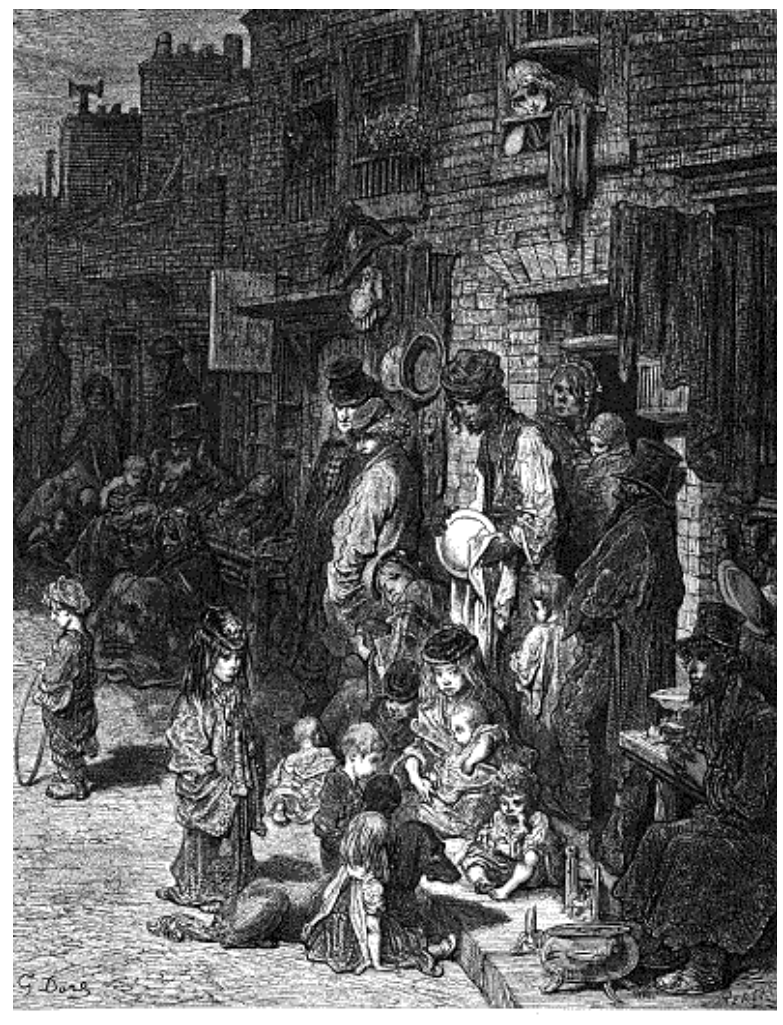

WENTWORTH STREET, WHTTECHXPEL. 
Nas outras grandes cidades do mundo a situação era semelhante. Mas se o jardim inglês refletia comunhão com a natureza, o jardim francês refletia o poder civilizatório da razão no controle da natureza e sociedade. Este ideal estava expresso na geometria racional, rígida, e simétrica, características que por continuidade se fizeram presentes no traçado urbano. $O$ plano de Georges-Eugène Haussmann para a reforma de Paris, em 1860, apagou grande porção da cidade medieval. Considerada imprópria aos "novos tempos", seu traçado espontâneo de becos e vielas foi substituindo por um desenho "moderno", que na verdade foi uma continuidade à tradição barroca já presente no palácio de Versalhes. Estão claras neste plano as intenções estratégicas e totalitárias de Napoleão III. De seu palácio, com ampla visão, recebe o povo ao mesmo tempo em que o controla.

A concepção haussmanniana de cidade foi de grande influência no mundo todo e se definiu como propulsora de uma linha de raciocínio modernista que teve continuidade até os dias de hoje. $O$ modo de pensar a articulação da cidade através de grandes avenidas, somada à tendência de valorizar o transporte rodoviário, inspirou inúmeros projetos que marcaram profundamente o rumo do crescimento das grandes metrópoles do século XX. Podemos observar seus preceitos nas reformas de Moses para Nova lorque, na reestruturação da orla no Rio de Janeiro por Pereira Passos, no plano de avenidas de Prestes Maia em São Paulo e no projeto de Lúcio Costa para o plano piloto de Brasília. A inserção da natureza na cidade, por esta concepção, difere da inglesa por ser condicionada a uma trama pautada pelo pragmatismo técnico, não é orgânica e desconsidera as condições geomorfológicas preexistentes.

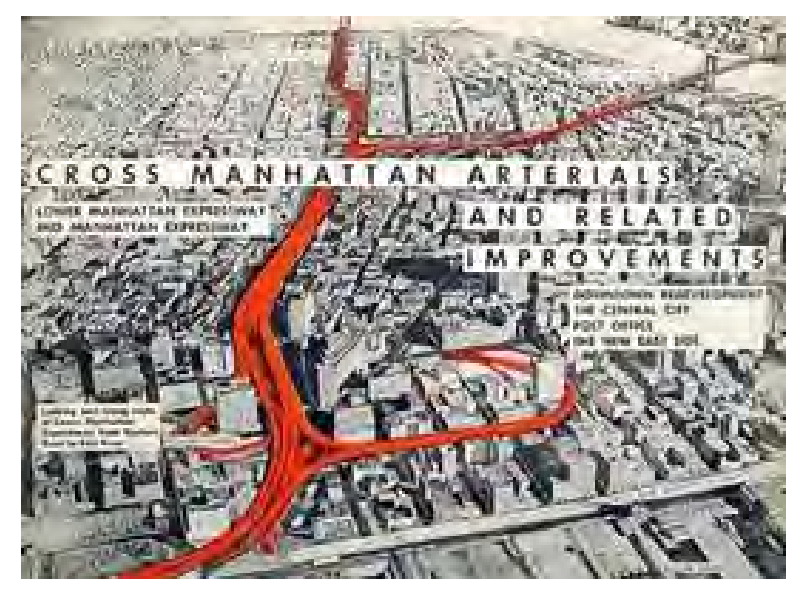

Figura 6: Plano de Moses: Sistema de auto-estrada urbana para Manhattan. Fonte: http://tenementmuseum.blogspot.com/2009_08_01archive.html

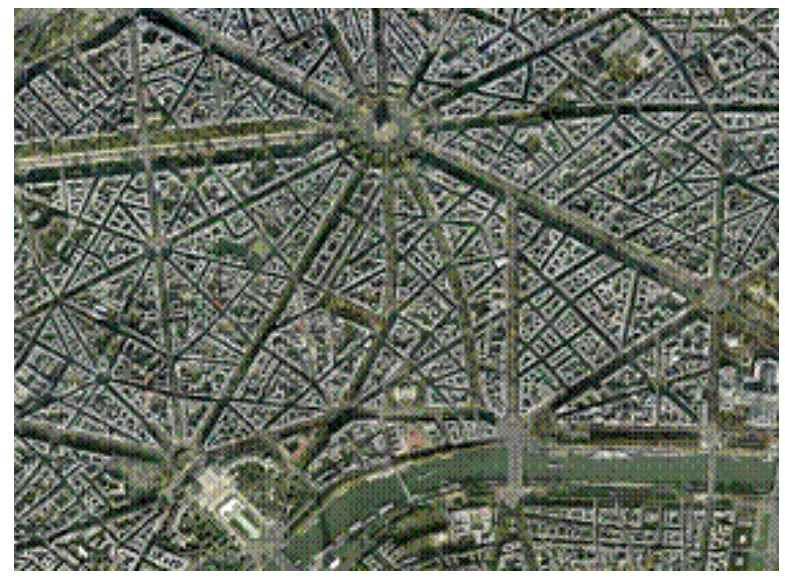

Figura 7: Paris de Haussmann Fonte: Google Earth 


\section{CAMILLO SITTE E A CIDADE TRADICIONAL}

No fim do século XIX esta linha de pensamento de inspiração francesa já contava com um importante opositor: o austríaco Camillo Sitte. O espírito de sua obra está na crítica à construção das cidades a partir das primeiras experiências após a revolução industrial, principalmente ao projeto de Haussmann para Paris.

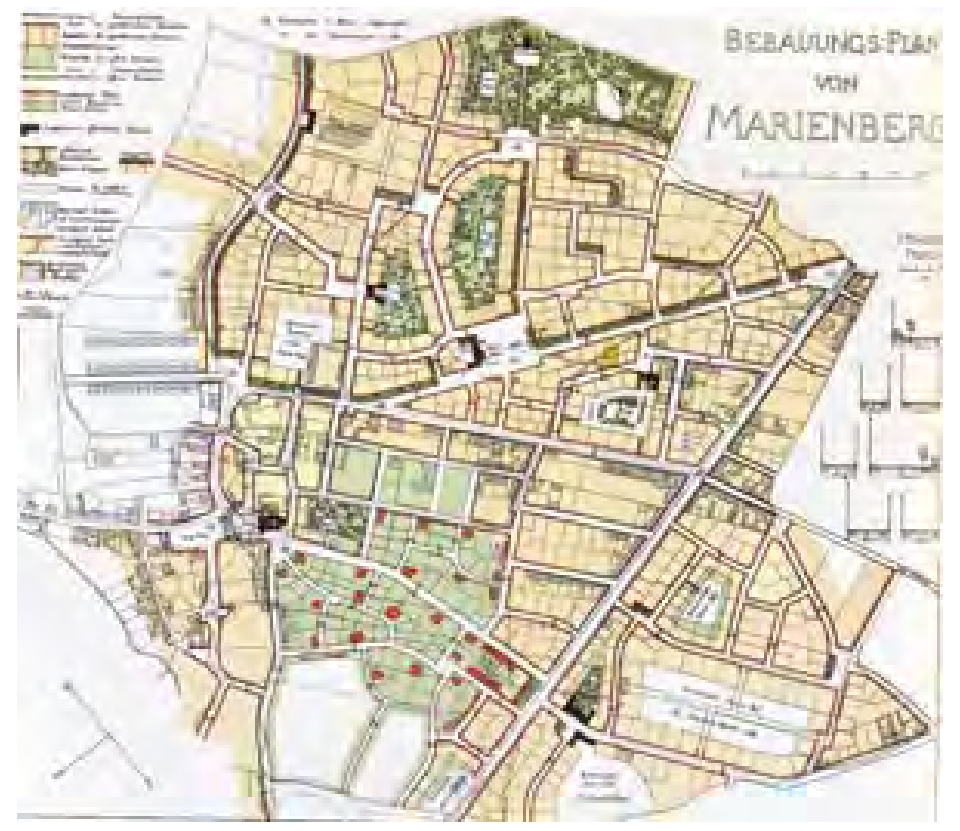

Figura 8: Plano que Camillo Sitte elaborou para Marienberg, em 1903. Fonte http://www.aeiou.at/aeiou.encyclop. data.image.s/s606159.jpg

A principal contribuição de Sitte está na valorização de aspectos mais sensíveis e fenomenológicos presentes no traçado irregular das cidades medievais, na forma como se localizavam nas praças as fontes e os monumentos, e nas características humanas que se perderam com a imposição demasiada de uma lógica cartesiana na ordenação do espaço urbano ${ }^{5}$. Defendeu também o valor da natureza na cidade muito além de seu sentido estético, constituindo um elemento indispensável à saúde da população ${ }^{6}$. Este caráter pitoresco, capaz de evocar sentimentos essenciais de comunidade e laços afetivos entre população e lugar, preserva e mantém presente o seu genius loci ${ }^{7}$, cuja perda é fator determinante na qualidade do meio ambiente urbano. A influência de Camillo Sitte foi e continua a ser de grande importância no pensamento urbanístico.

\footnotetext{
5 A Construção das Cidades Segundo seus Princípios Artísticos

$6 \quad$ O Verde na Metrópole

7 Literalmente "o espírito do lugar". $\mathrm{Na}$ abordagem fenomenológica da arquitetura é definido por um conjunto de características sócio-culturais, estéticas, espaciais e de hábitos que estabelecem vínculos psicológicos e afetivos profundos entre a população e o lugar.
} 


\section{AS CIDADES JARDIM}

Frente ao impacto da industrialização sobre as cidades, no final do século XIX o urbanismo se afirmava como importante disciplina. $\mathrm{Na}$ busca por unir o que existia de melhor na vida do campo e na vida urbana, surge na Inglaterra o modelo de cidade jardim. Hebenezer Howard, seu idealizador, buscou o equilíbrio necessário entre meio construído e natureza, o ideal da vida comunitária ligada à natureza e o fortalecimento de vínculos afetivos entre a população e o lugar, uma clara referência aos socialistas utópicos. Os estudos e cálculos de seu livro demonstra a busca de viabilidade para um projeto social em grande escala, reorganizando a sociedade dentro de uma estrutura autossustentável de comunidades cooperativas.

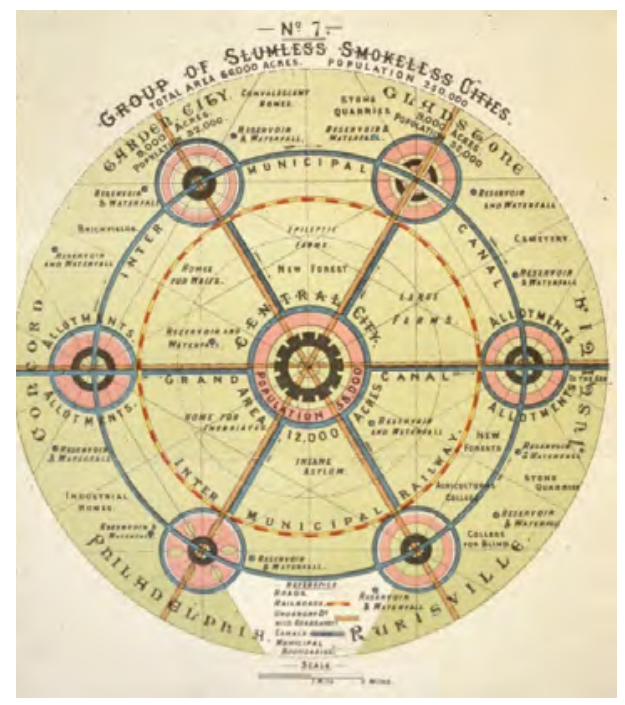

Figura 9: Diagrama n.o 7. http://history.sandiego.edu/GEN/ filmnotes/images2/howard3b.jpg

Em seus esquemas teóricos representou um conjunto de núcleos urbanos com crescimento limitado por cinturões verdes, conectados a um núcleo maior por eficiente sistema de transporte. Seu modelo propunha o desenvolvimento de cidades num grande entremeado de natureza e áreas construídas.

Barry Parker e Raymond Unwin deram a este modelo sua realização física. Primeiro para a aldeia de New Earswick (1902), depois no projeto para Letchworth (1908), a primeira cidade jardim. A partir da publicação do livro de Camillo Sitte, a dupla assimila uma estética mais orgânica assim como maior ênfase nos espaços de lazer e na integração das classes sociais. No projeto para o bairro londrino de Hampstead, Unwin reduziu de $40 \%$ para $17 \%$ o solo destinado às ruas, e acresceu a área verde de $17 \%$ para $55 \%$ do total. A individualidade e identidade do lugar foi um preceito importante, conciliando a ordenação do desenho com a naturalidade da topografia. 


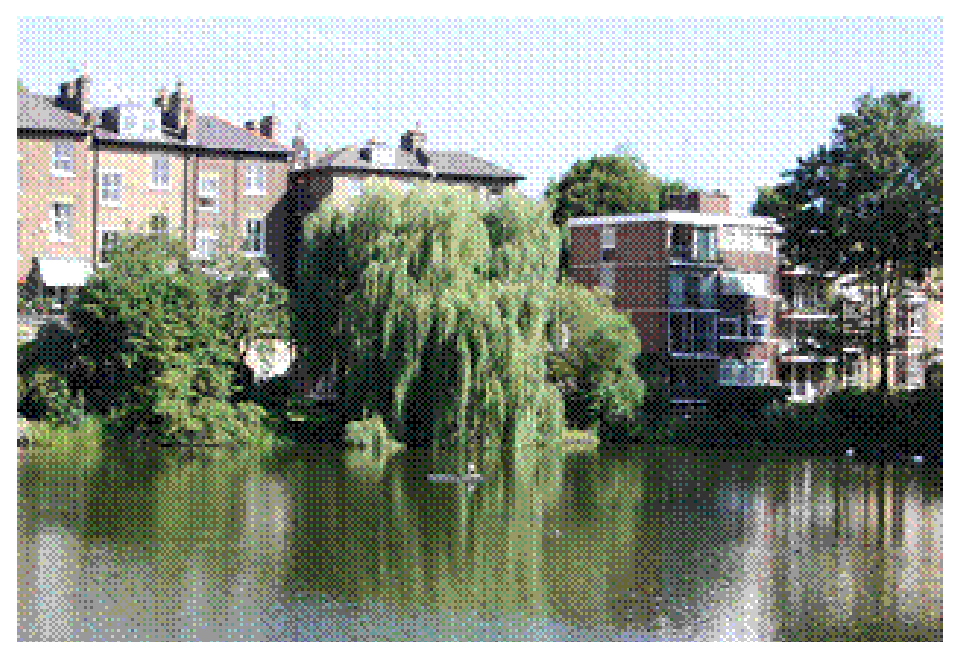

Figura 10: habitação junto ao lago do parque de Hampstead, fonte: Lotufo 2010.

\section{A CONTINUIDADE DA ESCOLA FRANCESA}

Do outro lado do oceano, sobretudo em cidades norte americanas, um movimento urbanístico seguia os preceitos racionais e clássicos da escola francesa, com grandes bulevares e edifícios monumentais de inspiração renascentista, o City Beautiful. Nascido ideologicamente na Europa esta tendência culminaria como modelo ideal de cidade para os regimes totalitários, de Berlim à Moscou. A mente por trás deste movimento foi Daniel Hudson Burnham, arquiteto autor de alguns dos primeiros arranha-céus de Chicago, cidade cujo plano em 1909 foi sua obra mais importante. Outro importante exemplo da aplicação dos princípios deste movimento foi o plano para Washington D.C em 1902, também de Burnham. ${ }^{8}$

Esta linha de raciocínio "arrasa quarteirão", com clara primazia da razão sobre a sensibilidade, seguia também seu curso através de outro francês, Tony Garnier e sua cidade industrial. Apresentada numa exposição em Paris em 1904 foi uma proposta pautada pela técnica, por cálculos, e pelas novas possibilidades construtivas e estéticas do concreto armado. Suas ruas, traçadas numa malha ortogonal regular, obedeciam a uma hierarquia rígida e seus canteiros e espaços verdes eram condicionados racionalmente à trama. Seu plano enfatizou o zoneamento urbano, organizando os diversos usos de forma racional na cidade, um funcionalismo baseado na linearidade da produção industrial.

$8 \quad$ HALL. Cidades do Amanhã 


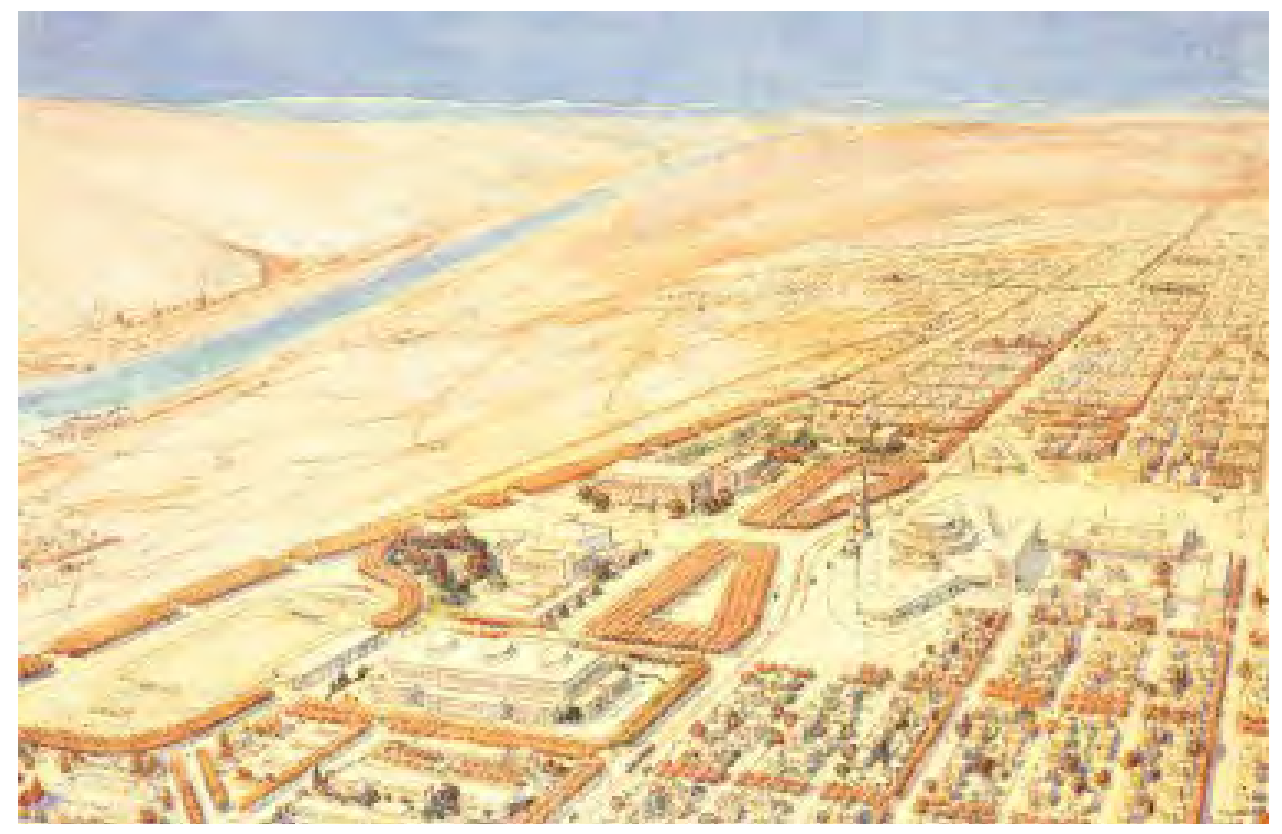

Figura 11: a Cidade Industrial de Tony Garnier. http://santileia.blogspot.com/2007_07_08_archive.html

\section{PATRICK GEDDES E A RPAA}

Por outro lado, o que Howard propunha sobre as cidades jardins o inglês Patrick Geddes, planejador e biólogo, aplicava conceitualmente na escala regional. Geddes foi responsável pela introdução do conceito de região ao planejamento urbano. Sua proposta está em clara oposição ao embelezamento monumental do City Beautiful. O planejamento, para Geddes, deveria começar com o levantamento geográfico da região, de seus recursos naturais e humanos e das complexidades resultantes desta interação. Para Geddes o modelo de ocupação definido pelos "elementos mais primevos e rudes da Era Industrial... desperdiçava recursos e energia, minimizava a qualidade de vida... produzia desemprego, subemprego, enfermidade e loucura..."

As ideias de Geddes terão grande importância na criação em 1923 da RPAA, Regional Planning Association of America, grupo do qual participou entre outras figuras importantes, Lewis Munford, Clarence Stein, Benton Mackay e Frederick Lee Ackerman. O RPAA, ao apoiar-se no conceito de regiões, cada uma delimitada com base em entidades geográficas naturais, buscou um rompimento com as vias convencionais de remodulação das cidades. A população e os serviços deviam se distribuir pela região de um modo a conservar tanto os valores humanos como as vantagens naturais do

MUMFORD. A cidade na história. 
lugar. Seu programa incluía a criação de grupos de cidades jardim e a promoção de planejamento para extensas áreas como a Trilha Apalachiana e a bacia do Vale do Tennessee ${ }^{10}$.

Ainda que na época o automóvel fosse visto como a grande oportunidade de desafogamento dos centros urbanos e critério para a reorientação do desenvolvimento de ocupação territorial, foi uma preocupação básica do RPAA o uso eficiente da energia, principalmente a gasta em transporte. Assim deveria existir o máximo de produção de alimentos, manufaturas, e materiais na própria região, inclusive a geração de energia elétrica. As trocas inter-regionais se dariam somente naquilo que a região não fosse capaz de produzir. Mas a melhor expressão de seus ideais, como veremos adiante, se deu na Inglaterra no 2.0 pós-guerra.

\section{A CARTA DE ATENAS}

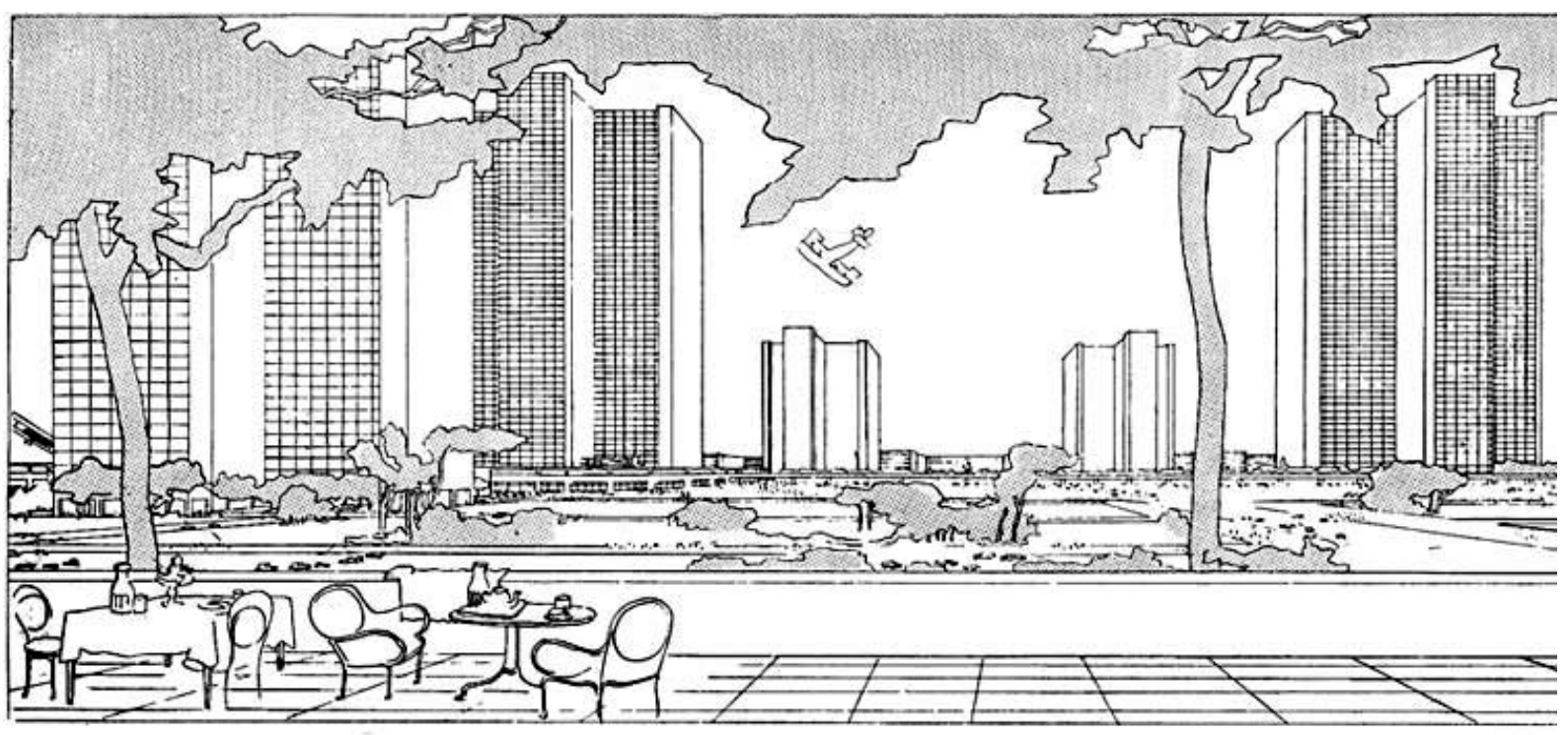

Figura 12: croqui de Le Corbusier.

Fica evidente ao leitor da Carta de Atenas que mesmo a vertente racionalista da arquitetura moderna se preocupou com a cidade enquanto organismo adaptado e integrado ao meio natural. Le Corbusier desejou que a ordenação racional do espaço urbano produzisse uma relação harmônica entre cidade e campo. Através da insolação e ventilação naturais e presença maciça da vegetação, prover-se-ia "o próprio tempero

HALL. Cidades do amanhã. 
da grande plástica geométrica introduzida na arquitetura contemporânea pelo ferro e pelo concreto armado" "11. A habitação deveria ser planejada de modo a garantir tempo livre ao trabalhador para que usufruísse destes espaços públicos na cidade.

No entanto seu idealismo tecnicista seguia o caminho de Tony Garnier impondo à natureza uma conformação artificial. A ideia da "torre no parque" tinha como objetivo liberar grandes áreas verdes e garantir a densidade necessária para viabilizar as instalações coletivas. Percebemos que nada se previa da agressiva presença do automóvel na cidade contemporânea ao idealizar parques ao longo de avenidas. Sabemos hoje o quanto estes parques tendem a ficar vazios e impróprios para lazer e convívio.

Peter Hall considera que este modelo, assim como o City Beautiful, difere das outras propostas urbanísticas por não estar alinhada com os ideais socialistas utópicos do fim do século XIX, mas imbuído de intenções totalitárias ou financeiras. Talvez por isso, este modelo que divide o solo urbano como uma máquina, em zonas por função, e se apoia no uso intensivo do automóvel, tenha se adequado tanto aos propósitos dos 'planejadores' do século XX, para quem a cidade foi sempre vista como oportunidade de especulação e enriquecimento de setores privilegiados. Do zoneamento monofuncional para a segregação socioespacial foi um passo espontâneo, impulsionado pela supervalorização do solo e por um planejamento frouxo, defendido por ideologias neoliberais que têm promovido seu lucro ao custo da degradação ambiental e social.

\section{ORGANICISMO}

Frente à ênfase mecanicista da arquitetura moderna o organicismo oferecia a contrapartida necessária para equilibrar seus excessos. Com forte expressão nos EUA na obra de Frank Lloyd Wright e na Europa com Alvar Aalto, tratou-se duma corrente fortemente alinhada com o urbanismo inglês. O que irá caracteriza-la é a forma como a construção se adapta ao lugar e sua inserção na paisagem, seguindo a lógica da topografia, dos sistemas vivos e dos cursos d'água. Na escala urbana Wright apresentou o modelo das Broadacre City, uma urbanização espalhada no território num movimento contrário ao desenvolvimento urbano industrial, propondo uma integração harmoniosa com os ecossistemas naturais. Para ele a solução para salvar a sociedade estaria no retorno ao campo.

11 Precisões, p.89 


\section{Revista LABVERDE}
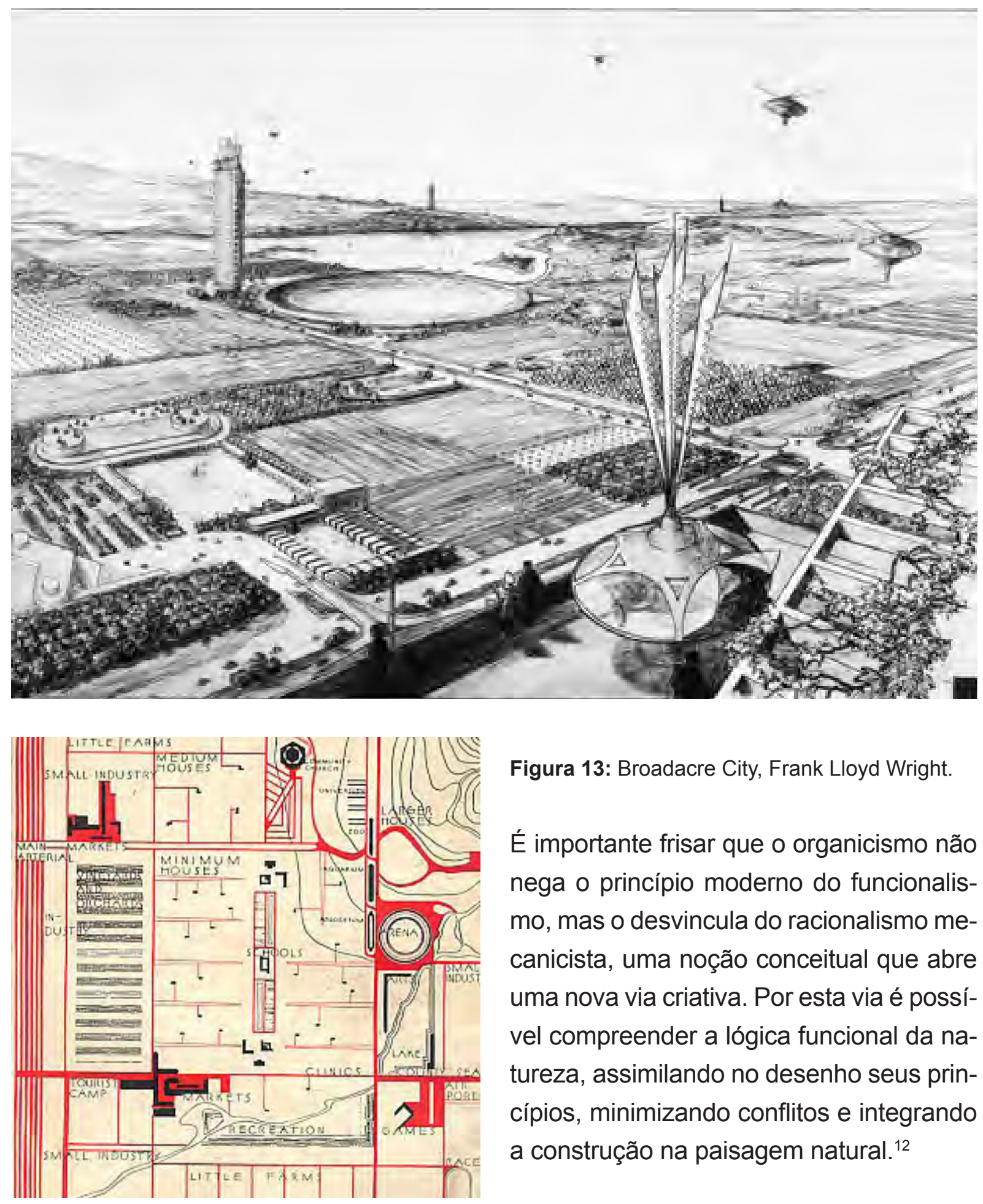

Figura 13: Broadacre City, Frank Lloyd Wright.

É importante frisar que o organicismo não nega o princípio moderno do funcionalismo, mas o desvincula do racionalismo mecanicista, uma noção conceitual que abre uma nova via criativa. Por esta via é possível compreender a lógica funcional da natureza, assimilando no desenho seus princípios, minimizando conflitos e integrando a construção na paisagem natural. ${ }^{12}$ 


\section{HABITAÇÃO E ENTORNO, O EXEMPLO DA HOLANDA}

No início do século XX, o pensamento de H.P. Berlage reunira várias influências no intuito de resolver os problemas da habitação na Holanda. Dos socialistas utópicos herdou a valorização do papel social da arquitetura, o que estimulou um inédito envolvimento dos arquitetos com a questão da habitação. A Escola de Amsterdam, que surgiu a partir de Berlage, fora influenciada pelo expressionismo alemão e pelas teorias de Camillo Sitte. O conjunto habitacional Het Schip (1913-1920), de Michel de Klerk é

notável exemplo de habitação social produzido pela escola de Amsterdam, com grande destaque ao cuidado que se deu a elaboração dos espaços interiores da quadra. Os edifícios desta escola, construídos agora em blocos urbanos coerentes, criavam um inédito valor simbólico e cultural à habitação proletária, pressupondo igualdade social.

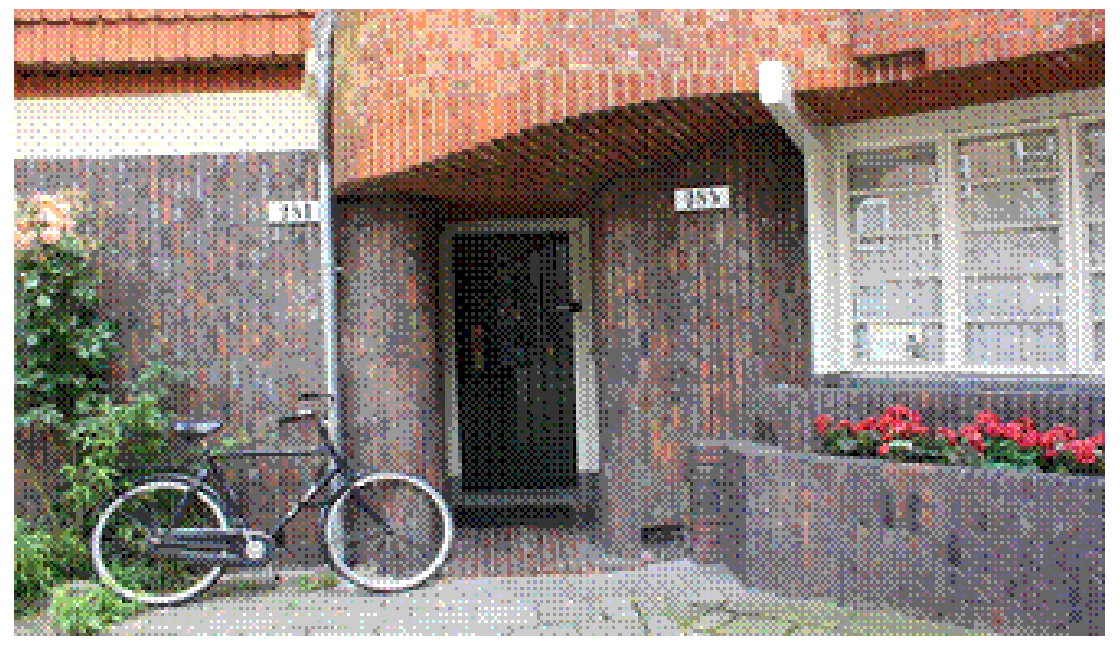

Figura 14: Het Schip, fonte: Lotufo 2010.

Nesta época J.J.P. Oud elaborava uma série de projetos em Roterdã, com influência do movimento De Stijl. Comprometido com as novas tecnologias construtivas rompeu com a es-

tética tradicional da Escola de Amsterdam, ainda que tivesse mantido muito de seus preceitos fundamentais. Os blocos se afastaram relativamente do princípio de fechamento, os jardins privativos cederam espaço para jardins coletivos e os espaços interiores foram se integrando com os exteriores possibilitando uma relação mais próxima com a natureza.

A Holanda recebera grande influência do modelo de cidade jardim. Mas distante dos ideais antiurbanos ingleses, este modelo foi incorporado numa confluência maior com as ideias de fechamento e adensamento inerentes ao pensamento de Camillo Sitte. Se por um lado distorceu-se a pureza original da proposta de Howard, possibilitou uma aplicação maior do modelo pelo mundo, não como cidades novas, mas como princípios norteadores para a expansão urbana. 
O projeto residencial Tuinwijk Zuid em Haarlem, cidade satélite de Amsterdam, de J.B. van Loghem, é notável exemplo da confluência dos princípios estéticos de Camillo Sitte e os princípios socioambientais de Howard. A quadra fechada em torno de jardins internos apresenta amplos portais, criando grande conexão com a rua e valorizando espaços abertos, verdes e de uso comunitário, sem eliminar o sentido de resguardo. Uma importante inovação deste projeto foi a inversão da posição tradicional entre frente e fundo. A cozinha, agora situada no lado da rua, liberou para a sala de estar uma inédita integração com o jardim interno. Isto inaugurou um novo sentido simbiótico entre a natureza e a construção. (LOTUFO)
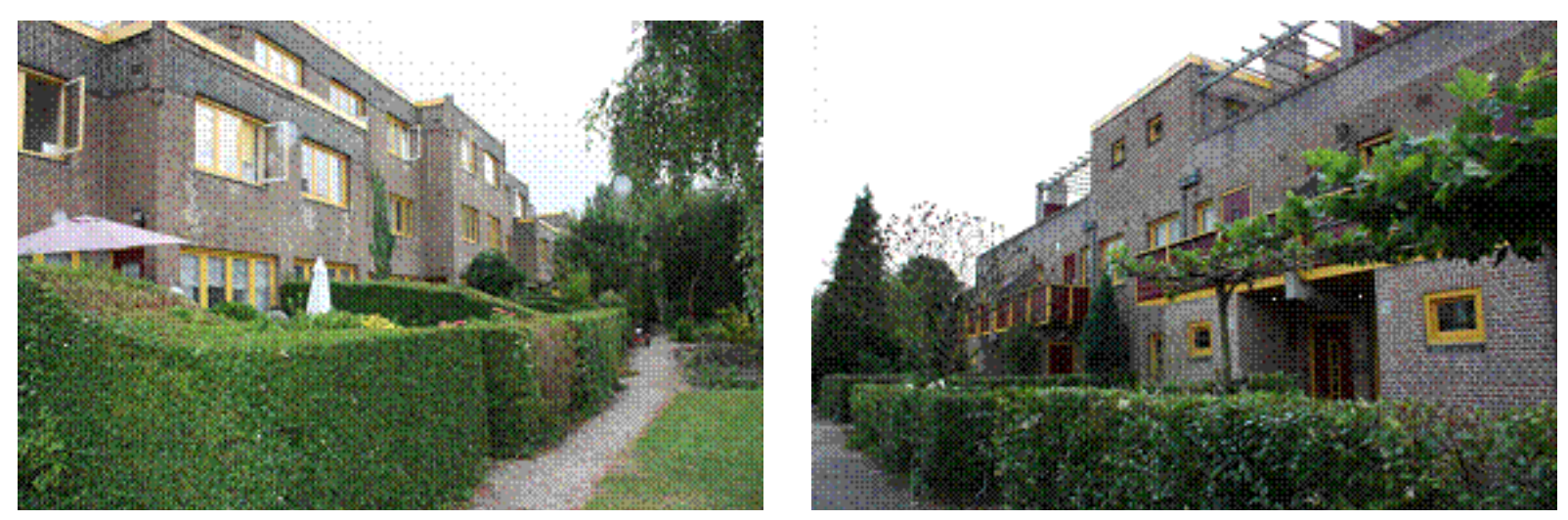

Figura 15: Tuinwijk Zuid, arq. J.B. Van Loghem, fonte: Lotufo 2010.

\section{DEPOIS DA 2ª GRANDE GUERRA}

A necessidade de reconstrução de Londres depois da Segunda Grande Guerra foi uma grande oportunidade de síntese e reflexão sobre a produção arquitetônica e urbanística da primeira metade do século. Com políticas de bem estar social e grande demanda por habitação o planejamento urbano e regional se torna tema central na Inglaterra. Neste quadro o plano para a Grande Londres de Patrick Abercrombie determinara um cinturão verde de preservação em torno da cidade evitando a expansão descontrolada e um sistema de parques conectando o cinturão ao centro da cidade, num grande entremeado de natureza e construção. 


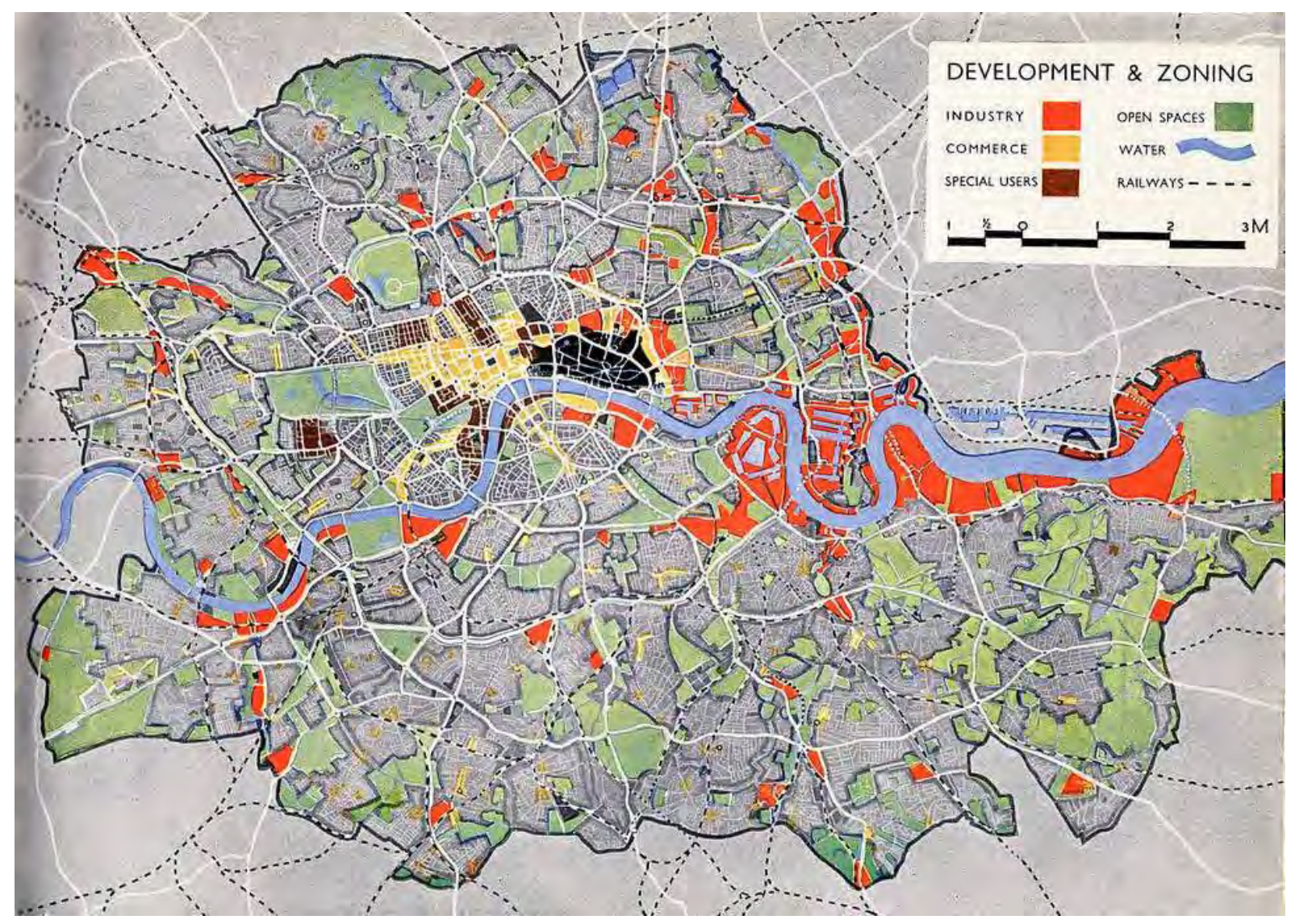

Figura 16: a esquerda, plano para Londres no segundo pós-guerra. Fonte: The County of London Plan. Explained by E.J. Carter and Ernö Goldfinger /

Figura 17: a direita, Cinturão Verde e Cidades Novas; Fonte: Revista Risco n.o 6, USP

A demanda do crescimento populacional foi atendida pelo New Towns Act (Plano para Cidades Novas), com a construção de novas cidades com elevada qualidade ambiental e cinturões verdes próprios. Seguindo os preceitos defendidos por Geddes e pelal RPAA este planejamento

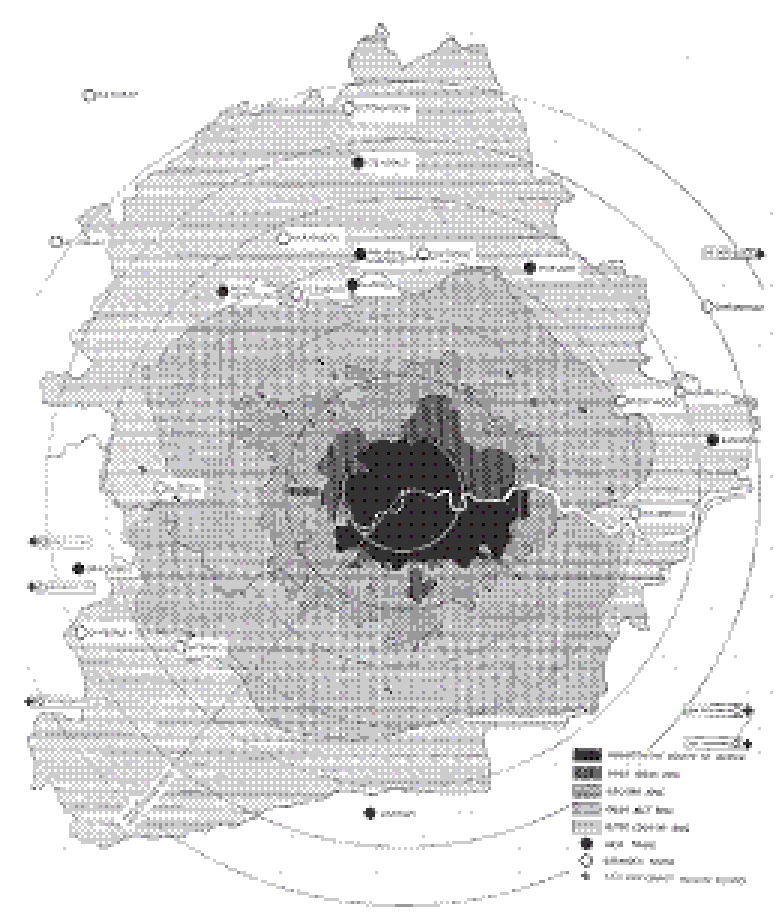
foi sensível às condições pré-existentes de ocupação do território. As cidades novas se desenvolveram a partir de pequenas vilas históricas e conectadas de forma eficiente entre si e com Londres. De 1946 até 1968 foram construídas trinta novas cidades baseadas no modelo de cidades jardim, 


\section{Revista LABVERDE}

recebendo grande parte da população que vivia em condições precárias, provendo emprego e alta qualidade de vida. Houvera até então um grande diálogo entre as experiências arquitetônicas e urbanísticas da Inglaterra e Holanda, o que alimentou de forma criativa as novas propostas do pós-guerra.

A bem sucedida experiência inglesa influenciou projetos pelo mundo. Na Suécia entre 1944 e 1952 foi implementado o plano diretor para a modernização de Estocolmo que renovou a cidade e criou uma série de cidades satélites com soluções de grande qualidade social e ambiental, salientando a preservação do patrimônio natural e cultural.

A estação central de Estocolmo tornou-se ponto de partida e chegada às diversas cidades novas. Estas, ao se desenvolverem ao longo da linha metroviária configuraram uma descontinuidade do território na forma de um "colar-de-pérolas". Suas estações centrais subterrâneas preservaram praças e áreas públicas acolhedoras para o encontro social.

Um exemplo notável foi a cidade de Välingby. Nas proximidades das estações, onde se concentram comércio e serviços, foi previsto um maior adensamento e verticalização. Na medida em que se afasta da estação a densidade construtiva diminui e a vegetação se faz mais presente, primeiro com edifícios baixos cujos jardins internos costumam ser usados para hortas comunitárias. Mais adiante aparecem casas unifamiliares em ruas tranquilas e ajardinadas. As passagens sob as ruas promovem total segurança para circulação de crianças, ciclistas e carrinhos de bebê. Não se veem muros, somente cercas baixas. Suas amplas áreas verdes formam o pano de fundo e são usadas para lazer e convívio com lagos artificiais onde durante os meses quentes as crianças brincam livremente.

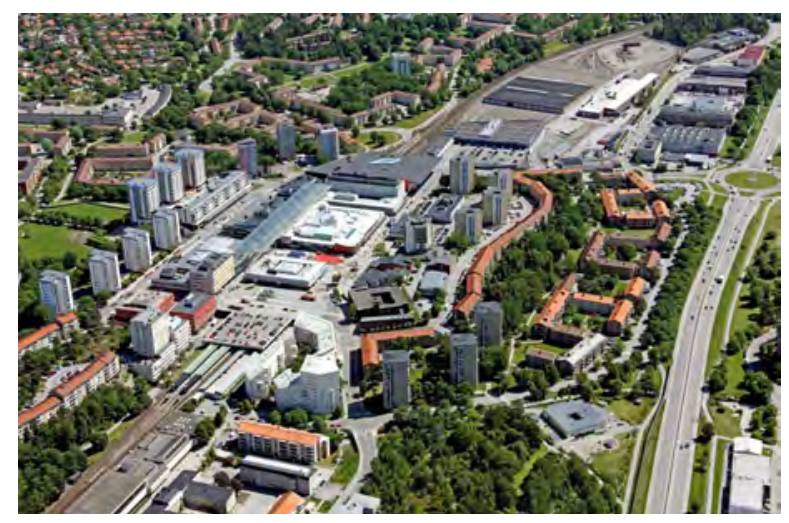

Figura 18: Foto aérea de Vällingby. Fonte: http:// www.vallingbycity.se/Om-Vallingby-City/

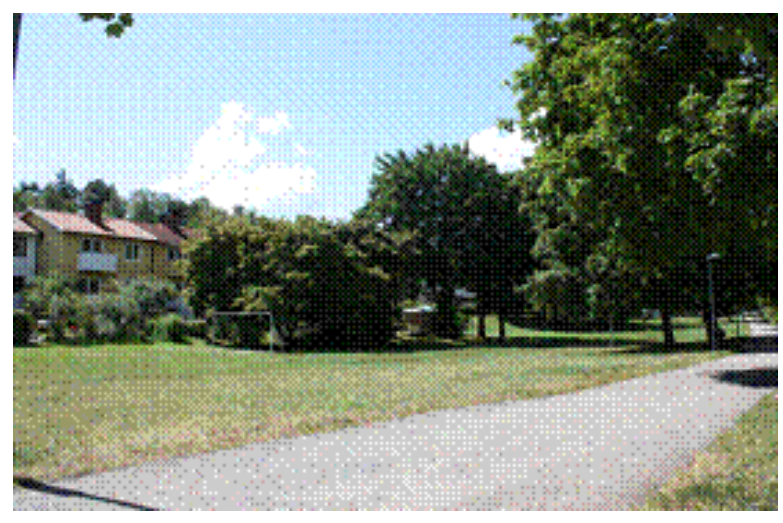

Figura 19: Residências e parque em Vällingby, fonte: Lotufo 2010. 
A conexão com o centro de Estocolmo é rápida e a paisagem das periferias suecas revela ao viajante o respeito que o urbanismo nórdico teve com o meio ambiente natural. Tanto Estocolmo quanto as cidades novas tiveram seu crescimento limitado por cinturões verdes. O distanciamento que a Suécia manteve do racionalismo internacional possibilitara certa continuidade aos valores próprios de caráter mais local, resultando numa arquitetura e urbanismo marcados por valores vernáculos e rurais. (LOTUFO)

\section{UMA REVISÃO CRÍTICA}

Nem tudo ocorrera tão bem como na Suécia. A partir da década de 50, com o automóvel se afirmando como modelo de transporte, os subúrbios dormitórios passam a ser gerados junto a autoestradas. Nos centros urbanos um processo de renovação começa a substituir antigas estruturas por novas, com aumento da malha viária e verticalização excessiva. A valorização imobiliária expulsa as classes menos privilegiadas para periferias precárias, longe de qualquer benefício que a cidade recebesse. A qualidade começa a ceder espaço para a quantidade ${ }^{13}$.

Uma nova visão crítica passa a reconsiderar as inter-relações e a proximidade das diversas funções no tecido das cidades tradicionais. Sentiu-se que as cidades contemporâneas haviam perdido uma vitalidade capaz de promover um relacionamento sadio entre a população e desta com o lugar. A cidade setorizada, esparramada e com suas funções separadas, passa a ser vista como uma proposta ultrapassada e insustentável.

Jane Jacobs ${ }^{14}$, uma das mais influentes críticas aos ideais modernistas, apontava a degradação social e ambiental dos projetos destinados à habitação, tanto para a população de baixa renda quanto para a classe média. E os espaços e prédios públicos, segundo ela, revelavam a incapacidade de se reconhecer e traduzir no desenho a diversificação da vida urbana e a relação com o lugar.

Um evento simbólico deste momento crítico foi a demolição, em 1972, do conjunto habitacional de Pruitt-Igoe em St. Louis, EUA. Símbolo do modelo falido de grandes conjuntos habitacionais periféricos servira para muitos programas de habitação pelo

13 HARVEY Condição Pós-Moderna.

14 The death and life of great American cities 1961 
mundo, como fora para o Brasil na década de 70 os projetos do BNH. Distante e isolado da cidade por vias de alto tráfego, declinou sob o peso de sua própria monotonia e de sua precariedade social e ambiental. (LOTUFO)

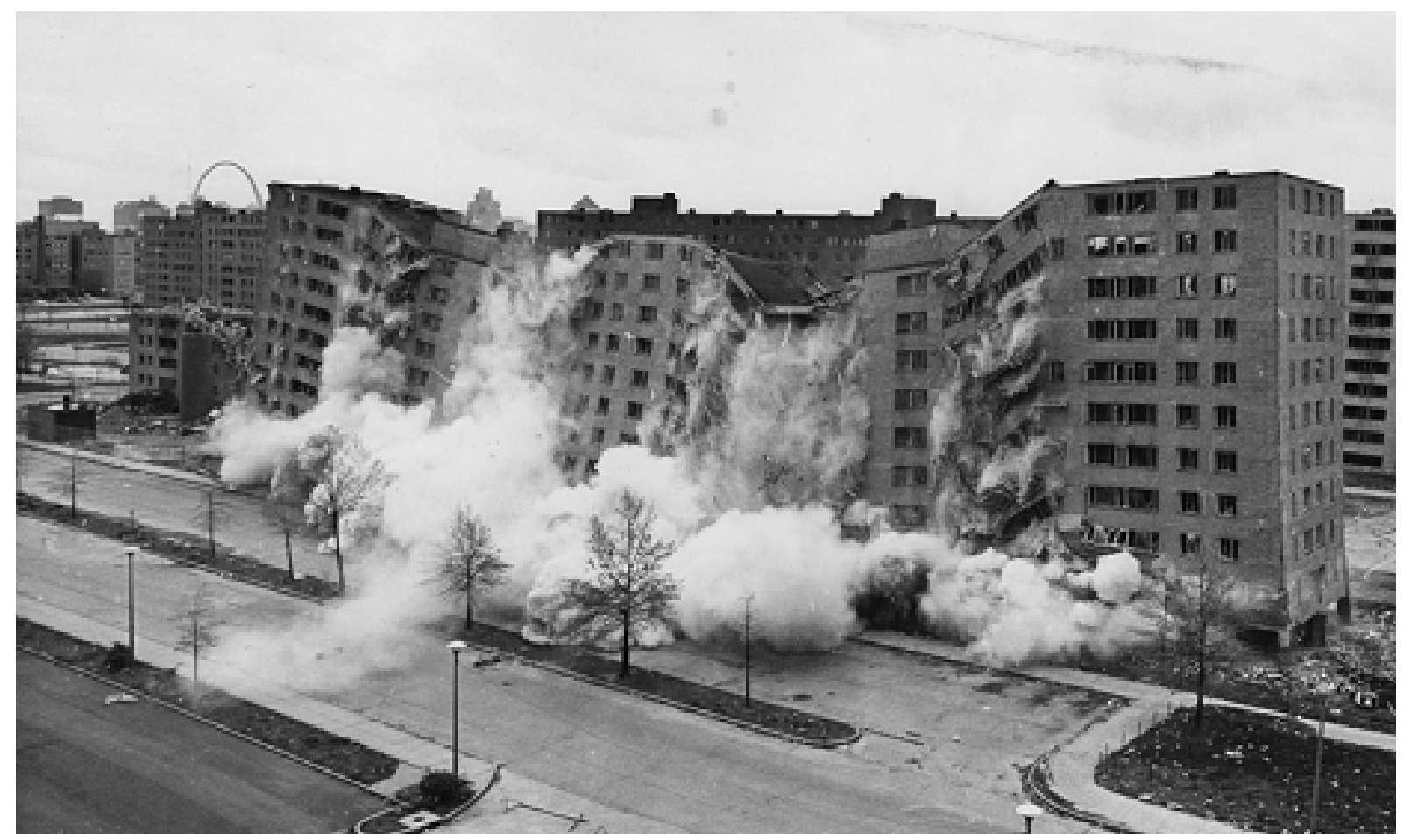

Figura 20: demolição de Pruitt-Iggoe, 1972. St. Luis EUA, fonte: Wikipedia.

Ganhava força a ideia de uma cidade onde fosse possível acessar grande parte de nossas necessidades em percursos a pé, portanto, com suas funções mescladas de um modo a oferecer maior autossuficiência aos bairros. Foi neste clima que surgiu o movimento Novo Urbanismo.

\section{A CONTRADIÇÃO PÓS-MODERNA}

A valiosa contribuição da crítica pós-moderna acabou também, como era de se esperar, assumindo um viés tendencioso em prol dos interesses particulares de certos setores dominantes, principalmente na oposição ao planejamento público.

Apoiados nos preceitos econômicos neoliberais e com forte protagonismo político, esses setores rejeitam tudo o que possa ferir seus interesses. Ao tratar o solo enquanto mercadoria sujeita à livre valorização, tem aprofundado a segregação socioespacial, 
reservando os benefícios da cidade a setores privilegiados, ignorando os impactos sociais e ambientais de seus empreendimentos e desconsiderando o papel socioambiental e cultural do espaço público.

Na verdade o que este modelo deseja é substituir o zoneamento do planejador pelo zoneamento do empreendedor. Não mais baseado no racionalismo e tampouco na sensibilidade ambiental, importa-se com o valor da construção enquanto produto de consumo, ou seja, seu apelo publicitário, seu potencial de venda e lucro. Deste modo, enquanto a classe alta e média se auto segrega em condomínios fechados e Shopping Centers, os mais pobres são desatendidos e varridos para as franjas da cidade, pois não podem arcar com o elevado custo de vida que se impõe sobre a cidade. O impacto ambiental deste processo é dramático, como podemos observar em São Paulo na invasão de áreas de preservação como a reserva florestal da Serra da Cantareira ao norte da cidade e os mananciais ao sul, elementos de nossa geografia que deveriam definir nosso cinturão verde. O impacto social se dá na ampliação do vão entre os ricos e pobres, na má qualidade de vida das favelas, cortiços e periferias, e na crescente violência e tensão social que atinge todas as classes.

\section{EM BUSCA POR UM MODELO SUSTENTÁVEL}

A nossa cidade contemporânea, ninguém há de duvidar, necessita de uma profunda revisão de seus processos de crescimento e organização. Retomando o tema inicial seria útil resumir os preceitos que definem o Novo Urbanismo e o Landscape Urbanism frente à necessidade de cidades mais sustentáveis.

\section{O Novo Urbanismo}

Segundo seus defensores, o Novo Urbanismo promove a criação e restauração de comunidades compactas vibrantes. Seus conceitos se aplicam tanto a novas cidades como a cura de cidades existentes. Estas comunidades devem possuir, mescladas no uso e ocupação do solo, habitação, emprego, lojas, lazer, escolas, parques, e serviços públicos essenciais, tudo em distâncias passíveis de serem percorridas a pé. 
O pedestre é valorizado pela boa qualidade das calçadas, ruas arborizadas e segregadas do tráfego. Quase tudo deve estar num raio de, no máximo, dez minutos de caminhada. A diversidade da vizinhança, com mescla de níveis de renda, idade, cultura e etnias, deve se dar tanto na escala das quadras quanto nos próprios edifícios.

O desenho arquitetônico e urbano deve buscar a beleza, o conforto e a identidade do lugar, prover usos comunitários e repeitar a escala humana. Seguindo os preceitos tradicionais de vizinhança seu centro e limites devem ser bem discerníveis. A alta densidade tem por objetivo facilitar a vida do pedestre, viabilizar comércio, serviço e infraestrutura. As construções devem prever o mínimo de impacto ambiental com o uso de tecnologia ecológica, eficiência energética e respeito aos sistemas naturais.

Uma rede ferroviária deve conectar as vizinhanças com a cidade e a metrópole. O sistema de transporte e mobilidade deve contemplar VLT (transporte leve sobre trilho), boas calçadas, ciclovias e sobretudo desestimular o uso do automóvel. ${ }^{15}$

\section{O Landscape Urbanism}

Segundo o Landscape Urbanism a cidade é um processo dinâmico, muito mais caracterizado por fluidez, retroalimentação (feedback), espontaneidade, organicidade do que por estabilidade, previsibilidade, racionalidade e linearidade. O uso do lugar, convencionalmente determinado por "programas" e "estruturas rígidas", deveria, antes, se basear em conceitos de "território", "potencial" e "estruturas adaptáveis". Ao focar essencialmente a superfície ao invés da forma, assume e assimila o espraiamento como fenômeno inevitável. Não se trata simplesmente de trazer a natureza para dentro da cidade, mas simultaneamente expandir a cidade na paisagem circundante, dissolvendo a fronteira tradicional entre cidade e campo. A ecologia e a teoria de sistemas são conceitos a serem incorporados no processo do projeto.

Para o LU a dualidade cidade/natureza deve ser superada através de uma fusão entre paisagem e construção. Para tanto propõe que a paisagem substitua a arquitetura como bloco básico de construção. Desde o trabalho sobre as calçadas até toda matriz infraestrutural propõe uma "grelha" de "sobreposições flexíveis, uma ecologia de sistemas em movimento numa rede complexa de interações".

15 www.newurbanism.org/ 
Toda esta complexidade conceitual requer novas formas de representação. Além das convencionais plantas, cortes e elevações deve-se lançar mão do uso de diagramas de campo, gráficos e mapas que descrevam processos dinâmicos, além de técnicas cinematográficas, coreográficas e programas avançados de computação gráfica. De fato, seus próprios defensores reconhecem que o problema representativo é por si um campo de pesquisa ainda a ser trabalhado.

A população urbana, agindo como "receptáculos da memória e desejos coletivos", tem papel determinante da definição do espaço público de modo a criar lugares para novos relacionamentos e possibilidades através de uma imaginação ao mesmo tempo geográfica e social. Fundamentalmente, o LU está se referindo à grande dicotomia entre natureza e civilização. As cidades e suas infraestruturas poderiam ser tão ecológicas como os ecossistemas naturais. Por isto deseja reposicionar a paisagem muito além de seu aspecto decorativo, e muito além de sua função mitigadora dos efeitos negativos da urbanização. Cada especialização de desenho urbano, em todas as escalas, devem se reunir numa pratica compartilhada onde arquitetura, paisagem e urbanismo se fundam sem que, no entanto, percam sua identidade própria (CORNER) ${ }^{16}$.

\section{CONFLITOS CONCEITUAIS E O VISLUMBRE DE UMA SOLUÇÃO}

Ambos os modelos oferecem preceitos importantes para o restabelecimento de um equilíbrio sadio entre natureza e civilização. Neles, as lições de Camillo Sitte, um humanista tradicionalista e Patrick Geddes, um biólogo progressista, parecem estar vivas. Talvez trabalhando juntos pudessem melhor integrar as ciências humanas com as biológicas e a tradição com a vanguarda.

16 http://sfsu-dai525.blogspot.com.br/2010/02/due-210-james-corner-terra-fluxus-from.html 
É notável que o geógrafo marxista David Harvey tenha sido citado por ambos os lados deste embate teórico. Isto nos mostra uma confluência no caráter das distorções e da apropriação demagógica que os modelos sofrem em prol de interesses políticos e econômicos. Contra o LU, dois artigos que citam e geógrafo se destacam no debate, uma de Leon Morenas para a revista Economic \& Political Weekly ${ }^{17}$ e outra de Greg Lindsay para a revista Fast Company ${ }^{18}$, criticando o projeto nova-iorquino High Line e seu principal protagonista, o político conservador e milionário Michael Bloomberg.

O LU desenvolveu a habilidade de interpretar o potencial geográfico e ecossistêmico e demonstrar as cidades como sistemas dinâmicos de fluxos, mas falhou em reconhecer as comunidades humanas também como ecossistemas, o que o torna alheio à função social da cidade. Em todo seu discurso parece não se importar com problemas como justiça social, congestionamentos, acessibilidade e segurança.

Estas brechas certamente serão usadas como justificativas para ações nada sustentáveis, reproduzindo processos de gentrificação e descuidando da cidade como um todo. O projeto do High Line tem recebido duras críticas mesmo em relação a suas características ecológicas, uma vez que seu alto custo de manutenção tem drenado recursos enquanto que os parques mais distantes da cidade declinam com a diminuição de investimentos públicos. Enquanto isso os imóveis de seu entorno estão em franco processo de valorização, o que acaba demonstrando os objetivos "ocultos" por detrás do discurso ecológico. O político republicano Michael Bloomberg parece desejar remodelar Manhattan de modo a promovê-la como um excelente lugar para negócios milionários e turistas endinheirados, ou seja, transformá-la numa vasta comunidade para ricos.

Michael Mahaffy ${ }^{19}$, um dos principais críticos do LU, parece coerente quando questiona se ao negar totalmente os princípios do NU a favor de "forças arbitrárias ou mesmo perigosas" o LU não estaria também negando a justiça social e a igualdade. Ao não promover uma integração entre urbanismo e transporte público, entre médias e altas densidades e entre classes sociais, estaria contradizendo a noção de desenho

\footnotetext{
17 http://www.indiaenvironmentportal.org.in/files/file/Landscape\%20Urbanism.pdf

18 http://www.fastcompany.com/1673037/david-harveys-urban-manifesto-down-with-suburbiadown-with-bloombergs-new-york

19 The Landscape Urbanism: Sprawl in a Pretty Green Dress? http://www.planetizen.com/ node/46262
} 
ecológico. Em fim, como idosos, pessoas com dificuldade de locomoção e pobres se locomoveriam por estes vastos espaços verdes para suas atividades e necessidades diárias? Para o LU, assim como para muitos neoliberais, a expansão urbana seria resultado de forças inexoráveis e não de escolhas históricas que uma vez compreendidas poderiam ser controladas.

Os defensores do LU parecem falhar em reconhecer as comunidades humanas como ecossistemas. Perpetuam uma fronteira conceitual entre o que é natural e o que é humano enquanto pregam dissolver fronteiras físicas entre campo e cidade. Resolvida esta contradição a questão se focaria na integração equilibrada destas duas dimensões. Os padrões da cidade tradicional passariam então a serem vistos, não como artifícios estilísticos, mas adaptações evolutivas orgânicas adquiridas no processo histórico. O conflito com os preceitos do NU não é absolutamente necessário.

Contra o NU o próprio Harvey escreveu para a Harvard Design Magazine em 1997 um artigo intitulado The New Urbanism and the Communitarian Trap. Neste artigo sua maior preocupação é de que se repita falácia modernista pela qual o ordenamento espacial é considerado uma base segura para uma nova ordem estética e moral. Uma de suas afirmações vai de encontro a um preceito básico do LU. A ideia de que o NU "não reconhece que a dificuldade fundamental do modernismo foi seu hábito persistente de privilegiar a forma espacial sobre o processo social". Estaria ainda viciado em querer aprisionar o processo histórico numa moldura fixa. Este vício estaria subtendido na relação entre o desenho e a ideologia de comunidade enquanto "apelo nostálgico".

Com significado ambíguo, a "comunidade", evocada como antídoto para a desordem social, acaba convertida em instrumento de controle. Frequentemente excludente fecha-se em si mesma contra os "outros", não tolerando comportamentos "estranhos" aos seus valores próprios. Isto é verdade tanto em países com grande desigualdade social quanto nos países com grandes comunidades de imigrantes. A dinâmica, os fluxos, a imprevisibilidade e a surpresa, tudo o que pode tornar a vida urbana rica e excitante é controlado. Neste sentido as comunidades podem ser barreiras e não facilitadores de uma mudança social. Não se pode simplesmente construir uma imagem de comunidade para quem não precisa, enquanto abandona aqueles que de fato necessitam devido sua situação de exclusão. Por isto o NU consiste numa potencial armadilha. Mais uma vez de encontro aos preceitos do LU, Harvey defende que o melhor antídoto é "compreender a urbanização como um grupo de processos flu- 
ídos numa relação dialética com as formas espaciais para as quais eles são origem e, por sua vez, os contém".

Arquitetura, urbanismo e planejamento são, a princípio, disciplinas sistêmicas. Devem, portanto, integrar diversos feixes de conhecimento. Somente uma visão integrativa e equilibrada pode curar diferentes perspectivas de seu viés ideológico. O que somos e o que queremos ser? Eis a questão a ser sempre respondida. Qual cidade e território nós desejamos? Este é o desdobramento espacial da mesma pergunta.

No âmbito do desenho urbano este dilema formalizou-se numa gama de posturas. Estes posicionamentos teóricos e ideológicos seriam de fato opostos ou poderiam, numa perspectiva mais elevada, se apresentarem como complementares? Se a resposta já está inserida na pergunta, integrá-los implica em resolver estas importantes contradições.

\section{REFERÊNCIAS BIBLIOGRÁFICAS}

CORBUSIER, Le. Carta de Atenas. CIAM-1933

CORBUSIER, Le. Precisões Sobre um Estado Presente da Arquitetura. São Paulo: Cosac Naify, 2004

HALL, Peter. Cidades do Amanhã. São Paulo: Editora Perspectiva, 2005

HARVEY,David. Condição Pós-Moderna. São Paulo: Edições Loyola, 1992

HERTZBERGER, Herman. Lições de Arquitetura. São Paulo: Martins Fontes, 2006.

HOWARD, Ebenezer. Cidades-Jardins de Amanhã. São Paulo: Editora Annablume, 2002

LIMA, Cathartina P.C. dos Santos, Natureza e Cultura: O conflito de Gilgamesh, em Paisagem e ambiente: Ensaios, n.o 18, São Paulo 2004

LOTUFO, José Otávio. Habitação Social para a Cidade Sustentável. Dissertação de Mestrado. São Paulo: FAU-USP, 2011 
MOSTAFAVI, Mohsen; DOHERTY, Gareth; (edição, vários autores). Ecological Urbanism. Harvard University: Lars Müller, 2010

MUMFORD, Lewis. A Cidade na História.São Paulo: Martins Fontes, 2008

OTTONI, Dácio Araújo B. A Arquitetura de Andrea Palladio e seu Relacionamento com a Cidade e o Campo. Desígnio 6. São Paulo: Annablume/FAU-USP , 2006

OTTONI, Dácio Araújo B. Cidade Jardim: Formação e Percurso de uma Idéia. Introdução à edição brasileira de Cidades-Jardins de Amanhã, de Hebenezer Howard. São Paulo: Editora Annablume , 2002.

SITTE, Camillo. A Construção das Cidades Segundo seus Princípios Artísticos. São Paulo: Editora Ática, 1992

\section{Sites visitados}

CORNER, James. Terra Fluxus

http://sfsu-dai525.blogspot.com.br/2010/02/due-210-james-corner-terra-fluxus-from. $\mathrm{html}$

DELLA MANA, Eduardo. Broadacre City: Meio Ambiente, Desenvolvimento Sustentável e Ecologia Social. Portal Vitruvius.

http://vitruvius.com.br/revistas/read/arquitextos/08.095/148

DUANY, Andres. Duany vs Harvard.

http://www.metropolismag.com.com/pov/20101103/duanys-vs-harvard-gds

HARVEY, David. The New Urbanism and the Communitarian Trap.

http://wsm.wsu.edu/stories/2008/Spring/1harvey.pdf

KRIEGER, Alex. Krieger to Duany 
http://www.metropolismag.com/pov/20101108/krieger-to-duany

LINDSAY, Greg. David Harvey's Urban Manifesto: Down With Suburbia; Down With Bloomberg's New York

http://www.fastcompany.com/1673037/david-harveys-urban-manifesto-down-with-suburbia-down-with-bloombergs-new-york

MEHAFFY, Michael. The Landscape Urbanism: Sprawl in a Pretty Green Dress? http:// planetizen.com/node/46262

MORENAS, Leon. Critiquing Landscape Urbanism. A view on New York's High Line.

http://www.indiaenvironmentportal.org.in/files/file/Landscape\%20Urbanism.pdf

TALEN, Emily. A tire in the park.

http://bettercities.net/news-opinion/blogs/emily-talen/13579/tire-park 